Terbit online pada laman web jurnal: http://jurnal.iaii.or.id

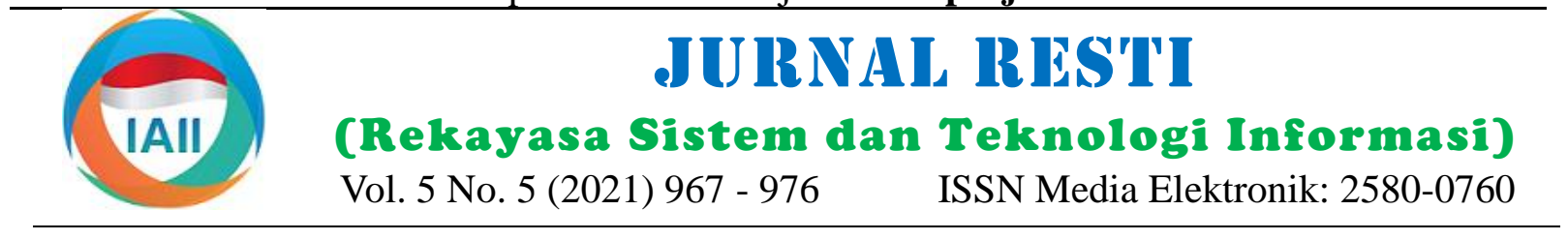

\title{
Sistem Keamanan Helm Berbasis Internet of Things dengan Fitur Pelacakan Menggunakan Android
}

\author{
Panji Wiratama Santoso ${ }^{1}$, I Nyoman Piarsa ${ }^{2}$, Ni Made Ika Marini Mandenni ${ }^{3}$ \\ 1,2,3 Program Studi Teknologi Informasi, Fakultas Teknik, Universitas Udayana \\ 1 panjisantoso20@gmail.com, ${ }^{2}$ manpits@unud.ac.id, ${ }^{3}$ made_ikamarini@unud.ac.id
}

\begin{abstract}
Helmet theft is a problem that is of concern to the public. Information Technology provides may resolve any problems, like Internet of Things-based system that can detect helmet theft and track the location of the helmet if it's stolen. This system is designed using a microcontroller device, namely Arduino which is attached to the helmet and motorbike with the help of the SIM800L v2, GPS Neo-6m, buzzer, and Bluetooth HC-05 which is connected to the master slave as an indicator of the safety of the helmet. The hardware on the helmet is connected to Firebase Realtime Database server so it can be connected with the user's Android application to monitor the state and location of the helmet. Android application displays maps to determine the position of the helmet, and can display notifications when the helmet is being stolen. The conclusion is this system can detect helmet theft with a maximum distance from the master and slave bluetooth connections of 10 meters, and the average data transmission from hardware to Firebase is 1,1 seconds, and can monitor status of the helmet and track the position of the helmet through the Android application with Android Jelly Bean (v4.3) operating system.
\end{abstract}

Keywords: Helmet theft, Internet of Things, Firebase, Android

\begin{abstract}
Abstrak
Pencurian helm merupakan salah satu masalah yang menjadi perhatian di kalangan masyarakat saat ini. Pemanfaatan Teknologi Informasi memberikan banyak kemudahan untuk mengatasi banyak permasalahan, seperti dengan menggunakan sistem berbasis Internet of Things yang dapat mendeteksi pencurian helm dan melacak lokasi helm jika tercuri. Sistem keamanan helm ini dirancang menggunakan perangkat mikrokontroler yaitu, Arduino yang dipasangkan pada helm dan motor dengan bantuan modul SIM800L v2, GPS Neo-6m, buzzer, dan Bluetooth HC-05 yang dikoneksikan master slave sebagai indikator keamanan pada helm. Perangkat keras pada helm dihubungkan dengan server Firebase Realtime Database sehingga dapat dihubungkan dengan aplikasi Android pengguna untuk memonitor keadaan dan lokasi dari helm. Aplikasi Android menampilkan maps untuk mengetahui posisi helm, dan dapat menampilkan notifikasi apabila helm sedang dalam keadaan tercuri. Kesimpulan dari hasil perancangan sistem keamanan helm yaitu, rancangan sistem pendeteksi helm berbasis IoT dapat mendeteksi pencurian helm dengan jarak maksimal dari koneksi bluetooth master dan slave adalah 10 meter, dan rata-rata pengiriman data dari perangkat keras ke Firebase adalah 1,1 detik, serta dapat melakukan monitoring status helm dan pelacakan posisi helm melalui aplikasi Android dengan sistem operasi Android Jelly Bean(v4.3).
\end{abstract}

Kata kunci: Pencurian helm, Internet of Things, Firebase, Android

\section{Pendahuluan}

Sepeda motor merupakan kendaraan yang pada umumnya paling banyak digunakan mahasiswa, kendaraan tersebut di parkir pada tempat yang Perkembangan teknologi saat ini telah memberikan disediakan pada kampus. Kebanyakan dari tempat parkir pengaruh yang besar untuk mengatasi berbagai masalah kampus tidak menyediakan fasilitas penitipan helm, dan dalam kehidupan sehari-hari, seperti di bidang petugas yang menjaga tempat parkir tidak dapat menjaga Teknologi Informasi. Era industri 4.0 ini erat kaitannya atau mengawasi setiap saat, sehingga mahasiswa dengan automasi kebutuhan yang difasilitasi dengan menyimpan helm pada sepeda motor mereka [1]. teknologi, seperti IoT (Internet of Things). Internet of Peristiwa kehilangan helm terjadi karena kelalaian Things adalah suatu konsep yang digunakan dalam mahasiswa yang tidak mengunci helm pada sepeda memperluas pemanfaatan dari jaringan internet yang 
berkembang cukup pesat mulai dari MEMS atau micro- master (perangkat pada motor) dan slave (perangkat electromechanical systems, konvergensi dari teknologi pada helm). Penggunaan koneksi master dan slave nirkabel, dan Internet [2]. Internet of Things dapat bertujuan sebagai indikator jarak antara helm dengan melakukan pengiriman maupun membaca data, sepeda motor. Sistem dirancang dengan modul GPS melakukan remote control, dan lain sebagainya. NEO-6M yang digunakan pada perangkat helm untuk Contohnya yaitu untuk benda dalam kehidupan sehari- mengetahui lokasi dari helm, dan juga buzzer yang dapat hari seperti bahan pangan, elektronik, dan termasuk digunakan sebagai alarm. Semua modul yang sudah benda hidup yang dapat tersambung ke jaringan global dijelaskan sebelumnya, digunakan sebagai sumber data dan juga lokal dengan menggunakan sensor yang dalam perancangan sistem ini, sehingga dapat dirancang dan dapat diaktifkan. IoT dapat mengarah menghindari terjadinya pencurian helm dan dapat pada suatu benda yang secara unik dapat mengurangi kerugian bagi pemilik helm yang diidentifikasikan sebagai suatu representasi virtual yang mengalami kejadian kehilangan atau pencurian helm.

berbasiskan internet. Beberapa penelitian yang meneliti mengenai revolusi dan implementasi IoT (Internet of Things) untuk industri 4.0 dengan memanfaatkan teknologi Internet of mendeteksi terjadinya pencurian helm, dan dapat Things dalam hal keamanan khususnya keamanan helm melakukan integrasi sistem Android dengan perangkat dengan perangkat Internet of Things, diantaranya yaitu keras IoT menggunakan Firebase. Perangkat keras pada [1] penerapan sistem untuk mencegah terjadinya motor dan helm dirancang dengan menggunakan modul peristiwa pencurian helm dengan menggunakan sensor Bluetooth HC-05 yang dapat membantu dalam magnetic reed switch sebagai pengunci helm, dan perancangan sistem penelitian, karena modul tersebut menggunakan Bluetooth HC-05 sebagai koneksi master dapat melakukan konfigurasi master dan slave yang dan slave sebagai indikator jarak antara helm dengan digunakan untuk indikator jarak keamanan pada sepeda motor, sehingga dalam penelitian tersebut dapat perangkat keras helm dan motor, yang memiliki dua menghasilkan suatu sistem yang dapat mendeteksi mode dalam modul tersebut yaitu Data Mode dan juga pencurian helm menggunakan protokol MQTT dan AT Command Mode [5]. Perangkat keras pada motor modul pendukung sistem berbasis Arduino. Penelitian menggunakan Arduino Nano sebagai perangkat lainnya [3] merancang sistem yang dapat melacak mikrocontroller dan baterai 9V sebagai daya pada kendaraan menggunakan Modul Relay, SIM808, dan Arduino, didasarkan karena perangkat keras motor Arduino Uno dengan mengukur keakuratan dalam hanya menggunakan satu modul yang tidak mengunci suatu sinyal satelit dan mengukur lama dari menggunakan tegangan tinggi dan arus pada baterai, waktu yang dibutuhkan untuk menerima dan sehingga dapat lebih efisien dalam perancangan mengirimkan pesan singkat yaitu informasi posisi atau perangkat keras pada motor.

lokasi kendaraan pengguna dan memutus sistem kelistrikan sepeda motor [3], penelitian lainnya [4] berupa perancangan sistem untuk perancangan sistem keamanan sepeda motor sebagai panduan untuk perancangan sistem keamanan sepeda motor berbasis Arduino-Android yang dapat dikendalikan melalui smartphone dan dirancang menggunakan modul Bluetooth HC-06 yang dapat diintegrasikan dengan perangkat mikrokontroler Arduino Uno [4]. Penelitian yang telah dikaji sebelumnya terdapat beberapa kelemahan, yaitu seperti tidak terdapat suatu sistem yang dapat melacak keberadaan alat tersebut apabila terjadi pencurian, sehingga apabila terjadi pencurian nantinya pengguna tidak mengetahui posisi helm.

Perangkat keras pada helm menggunakan Arduino UNO sebagai perangkat mikrocontroller, karena memiliki kelengkapan pin dan port lebih lengkap dibandingkan Arduino Nano, dan modul SIM800L v2 dapat berjalan dengan stabil menggunakan Arduino UNO. Modul GPS NEO-6M yang digunakan untuk mengetahui posisi helm, dapat melacak hingga 22 satelit di 50 saluran dengan mengonsumsi arus 45mA [6]. Modul SIM800L v2 dapat digunakan untuk melakukan pengiriman dan menerima data menggunakan layanan pesan singkat atau SMS, dan koneksi jaringan internet GPRS menggunakan perintah AT [7]. Sehingga modul SIM800L v2 dapat mengirimkan data yang didapatkan dari tiap modul ke Firebase Realtime Database yang merupakan database Berhubungan dengan IoT (Internet of Things) dan sistem realtime dan dapat menyimpan data pada cloud. pendeteksi ini serta melatarbelakangi masalah yang ada, Firebase Realtime Database memiliki dukungan dapat dilakukan penelitian dalam merancang perangkat berbagai platform seperti Android maupun website [8]. sistem yang dapat mendeteksi terjadinya pencurian helm dan mengetahui lokasi atau posisi dari helm yang telah dicuri dengan menggunakan sistem pendeteksi berbasis teknologi Internet of Things. Perancangan sistem ini dilakukan dengan menggunakan modul SIM800L yang dapat melakukan koneksi jaringan internet sehingga dapat mengirimkan data dari sistem ke aplikasi Android dengan menggunakan Firebase. Selain itu, sistem ini menggunakan modul Bluetooth HC-05 sebagai koneksi

Data yang telah dikirimkan pada Firebase akan dibaca pada aplikasi Android, yang merupakan sistem operasi pada perangkat telepon pintar (smartphone) berbasis Linux, dan menyediakan berbagai macam platform terbuka untuk para pengembang agar dapat menciptakan suatu aplikasi [9]. Firebase Realtime Database dapat memungkinkan untuk menyimpan dan sinkronisasi data secara realtime dan data tersebut akan secara otomatis 
melakukan pembaruan dengan data terbaru ke pengguna mengatur kondisi alarm pada helm yang digunakan [10], [11].

\section{Metode Penelitian}

Penelitian ini dilakukan melalui proses yang diawali dari melalui studi literatur, melakukan perancangan dan pembuatan alat, melakukan pengumpulan dan pengambilan data. Metode penelitian dari sistem pendeteksi pencurian helm berbasis IoT dijelaskan sebagai berikut.

\subsection{Gambaran Umum Sistem}

Gambaran umum bertujuan untuk menggambarkan alur dari sistem yang dirancang seperti pada Gambar 1 .

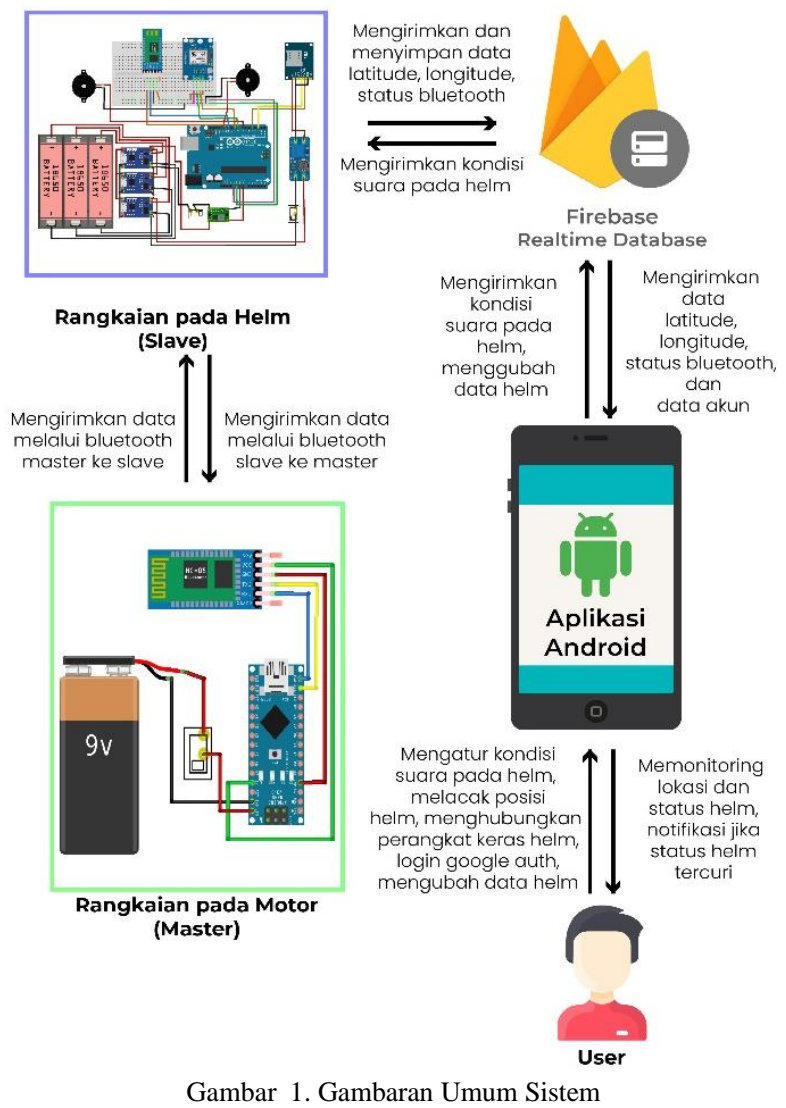
untuk mengetahui lokasi helm jika sudah mendekati posisi helm, dan pengguna dapat menekan tombol switch pada aplikasi Android dan akan mengubah data alarm_helm pada Firebase. Alarm akan berbunyi apabila data alarm_helm adalah " 1 ", dan jika "0" maka alarm helm akan mati, dan aplikasi Android akan menampilkan data helm ke pengguna. Aplikasi android dapat melakukan koneksi bluetooth ke perangkat keras helm (slave) untuk menyimpan data helm tersebut ke akun pengguna yang telah melakukan login menggunakan autentikasi Google dan mengirimkan data helm key baru. Perangkat keras pada helm akan mengirimkan data yaitu nama bluetooth yang selanjutnya akan disimpan pada Firebase Realtime Database.

\subsection{Diagram Use Case}

Use Case Diagram bertujuan untuk mengetahui fungsi yang terdapat dalam sistem dan dapat merepresentasikan interaksi antara aktor dengan sistem. Diagram use case penelitian ini dapat dilihat seperti pada Gambar 2.

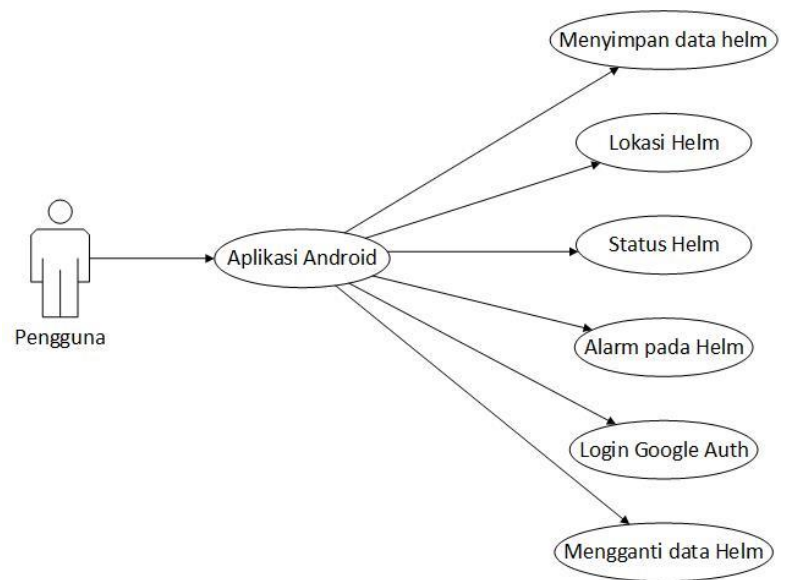

Gambar 2. Diagram Use Case

Pengguna dapat menggunakan aplikasi mobile berbasis Android dan dapat mengakses lokasi helm, status helm, dan suara pada buzzer di helm, yang telah dihubungkan dengan setiap perangkat pendukung yang ada pada sistem seperti modul GPS Neo-6m, Bluetooth HC-05, Alur proses sistem dimulai dari rangkaian motor SIM800L, dan buzzer. Pengguna dapat melihat lokasi (master) akan melakukan koneksi master slave helm melalui perangkat modul GPS pada helm seperti menggunakan modul Bluetooth HC-05 ke rangkaian latitude dan longitude, status helm didapatkan melalui pada helm (slave). Buzzer pada perangkat motor akan koneksi antara master dan slave pada modul Bluetooth berbunyi jika koneksi master dan slave tersebut terputus. HC-05, dan suara pada buzzer dapat dihidupkan dan Rangkaian pada motor akan mengirimkan data latitude dimatikan melalui aplikasi Android. Pengguna dapat \& longitude pada modul GPS Neo-6m, dan data menyimpan dan mengubah data helm pada Firebase bluetooth. Data tersebut dikirimkan ke Firebase Realtime Database, dan dapat melakukan login menggunakan koneksi dari SIM800L v2. Semua data menggunakan autentikasi Google.

yang telah disimpan pada Firebase, akan dibaca pada aplikasi Android pengguna, dan pengguna dapat melakukan monitoring lokasi dari helm tersebut.

\subsection{Database Sistem}

Pengguna juga dapat mengatur kondisi suara pada helm yang digunakan untuk mengetahui lokasi helm jika sudah mendekati posisi helm. Pengguna juga dapat

Perancangan database dalam Sistem Pendeteksi Pencurian Helm diperlukan karena dalam suatu aplikasi diperlukan basis data yang dapat menyimpan data di dalam aplikasi tersebut. Perancangan database sistem 
dapat dilihat seperti pada Gambar 3.

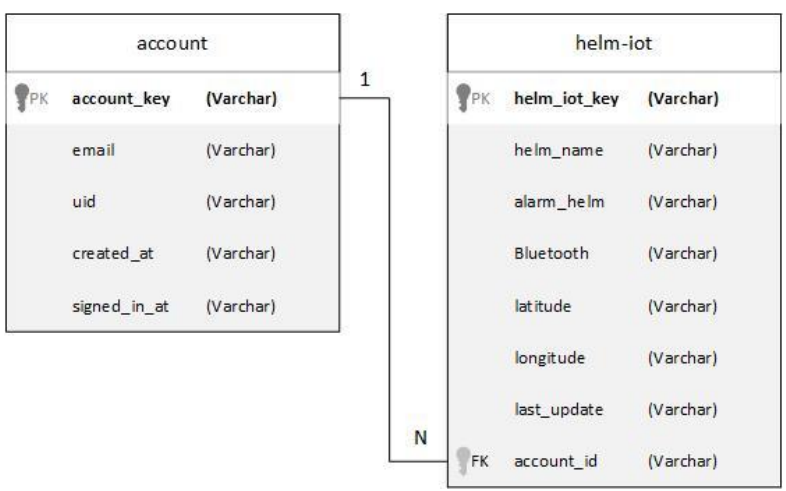

Gambar 3. Rancangan Database Sistem

Database sistem dirancang dalam Firebase Realtime Database dengan nama database helm-iot-test-default$r t d b$, yang memiliki dua tabel yaitu helm-iot dan account. Tabel account bertujuan untuk menyimpan data akun yang telah melakukan sign in pada aplikasi Android pengguna, tabel account memiliki 5 atribut yang merepresentasikan tabel tersebut antara lain yaitu, account_key, email, uid, created_at, dan signed_in_at. Tabel helm-iot bertujuan untuk menyimpan data perangkat keras helm yang telah didaftarkan melalui aplikasi android pengguna, tabel helm-iot memiliki 8 atribut yang merepresentasikan tabel tersebut antara lain, helm_iot_key, helm_name, alarm_helm, bluetooth, last_update, latitude, longitude, dan account_id yang memiliki fungsi yang berbeda-beda.

\subsection{Flowchart Sistem}

Flowchart rancangan sistem dari penelitian ini dapat dilihat seperti pada Gambar 4.

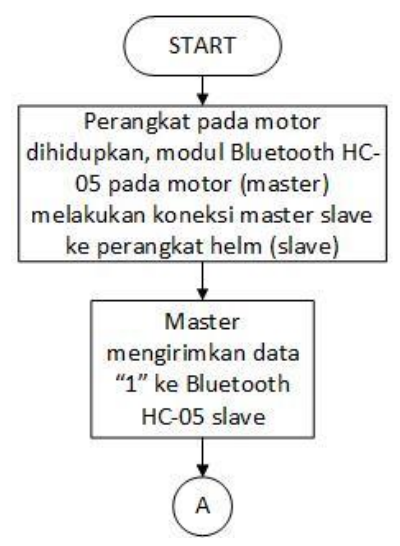

Gambar 4. Flowchart Rancangan Sistem pada Perangkat Motor

Alur flowchart dimulai dari perangkat pada motor dihidupkan, modul Bluetooth HC-05 pada motor (master) melakukan koneksi master slave ke perangkat motor (slave), dan master mengirimkan data "1" ke slave. Alur flowchart dari perancangan sistem pada perangkat helm dapat dilihat seperti pada Gambar 5.

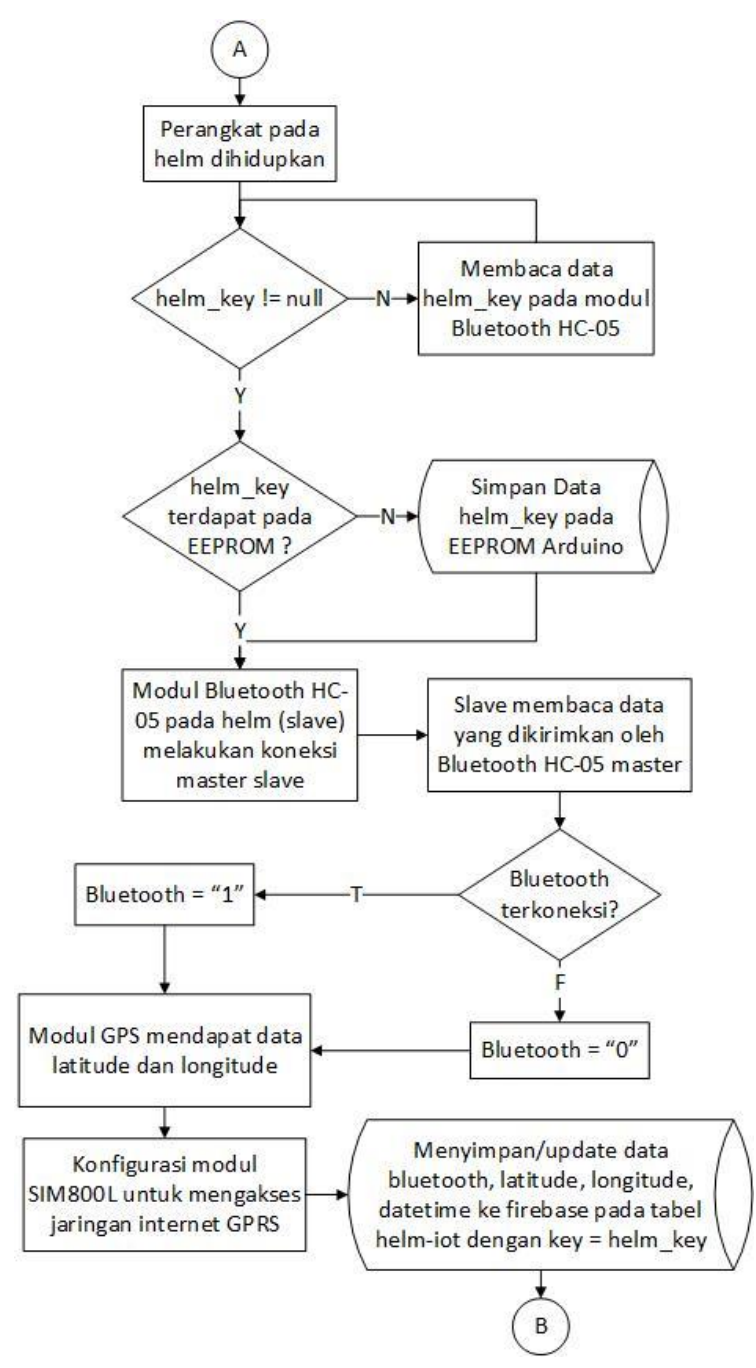

Gambar 5. Flowchart Rancangan Sistem pada Perangkat Helm

Alur flowchart dimulai dari perangkat keras helm dihidupkan, kemudian akan membaca data helm_key apabila tersedia maka akan menyimpan data tersebut pada EEPROM yang terdapat pada Arduino. Modul Bluetooth HC-05 akan membaca kembali data helm_key apabila tidak menerima data atau data tidak tersedia. Selanjutnya modul Bluetooth HC-05 pada helm (slave) melakukan koneksi master slave. Kemudian slave membaca data yang dikirimkan dari master, data bluetooth adalah "1" jika bluetooth terkoneksi maka, data bluetooth adalah "0" jika tidak terkoneksi. Modul GPS akan membaca data latitude dan longitude. Kemudian modul SIM800L akan dikonfigurasikan untuk koneksi menggunakan internet GPRS. Semua data tersebut akan disimpan pada database Firebase pada tabel helm-iot sesuai dengan id atau key dari helm tersebut, dan akan dilanjutkan proses pada aplikasi Android. Alur Flowchart dari perancangan sistem pada aplikasi Android dapat dilihat seperti pada Gambar 6. 


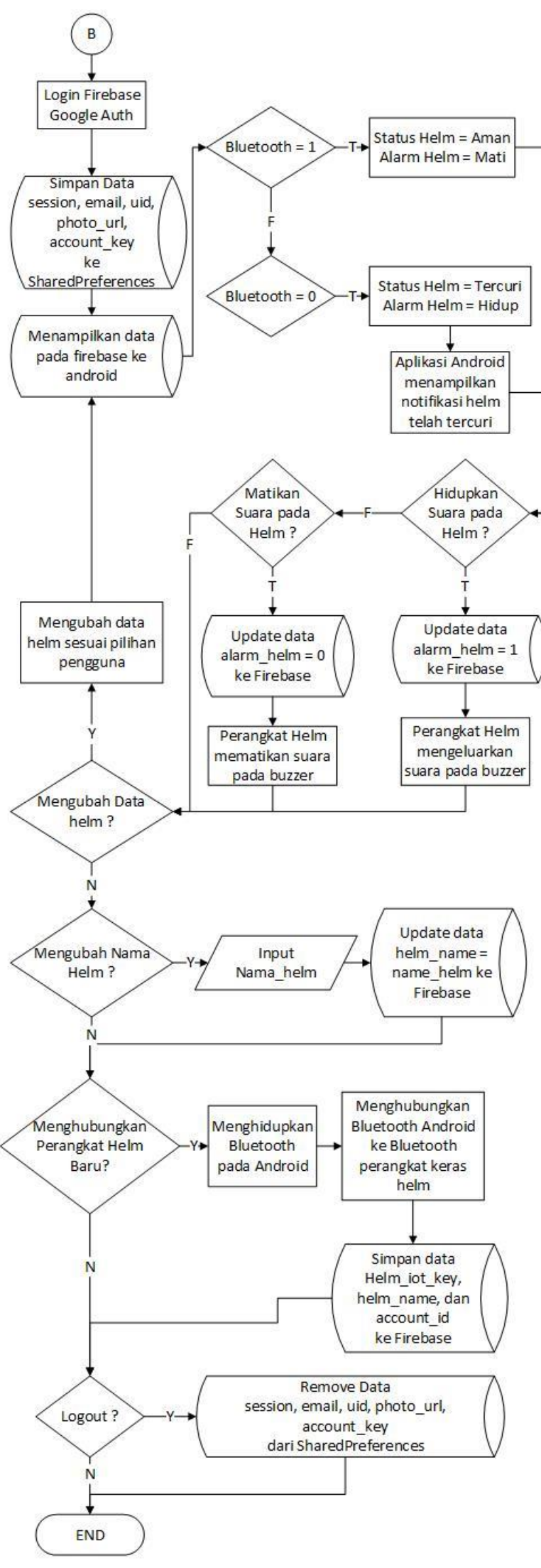

Gambar 6. Flowchart Rancangan Sistem pada Aplikasi Android

Alur flowchart dimulai dari pengguna melakukan login kedalam aplikasi menggunakan autentikasi Google dan ketika berhasil maka akan menyimpan data session, email, uid, photo_url dan account_key ke SharedPreferences. Data pada database Firebase ditampilkan pada aplikasi Android, data bluetooth "1" berarti status helm adalah aman dan alarm keamanan mati. Data bluetooth adalah " 0 " berarti status helm adalah tercuri dan alarm keamanan helm akan menyala/hidup dan aplikasi Android akan menampilkan notifikasi bahwa helm telah tercuri. Pengguna dapat menghidupkan alarm suara pada helm, dan sistem akan memperbaharui data alarm_helm menjadi "1" pada Firebase dan buzzer akan berbunyi. Pengguna juga dapat mematikan alarm suara pada helm dan sistem akan memperbarui data alarm_helm menjadi " 0 " pada Firebase dan buzzer pada helm akan mematikan suara.

Proses dilanjutkan dengan kondisi pengguna apabila ingin mengubah data helm maka sistem akan mengubah data helm sesuai pilihan pengguna dan jika tidak maka akan melanjutkan prosesnya. Pengguna dapat mengubah nama helm dengan memasukkan data nama helm baru dan akan memperbarui data pada Firebase sesuai dengan data helm tersebut. Pengguna dapat menghubungkan perangkat helm baru dengan menghidupkan bluetooth pada android dan menghubungkan bluetooth pada android ke perangkat keras helm, kemudian sistem akan menyimpan data helm_key baru, helm_name, dan account_id ke Firebase. Pengguna dapat melakukan logout dari sistem dan data yang tersimpan pada SharedPreferences akan terhapus, dan selesai.

\subsection{Perancangan Perangkat Keras}

Rancangan perangkat keras dari sistem ini terdiri dari dua perangkat keras yaitu perangkat pada sepeda motor dan helm. Perancangan perangkat keras pada sepeda motor dapat dilihat seperti pada Gambar 7.

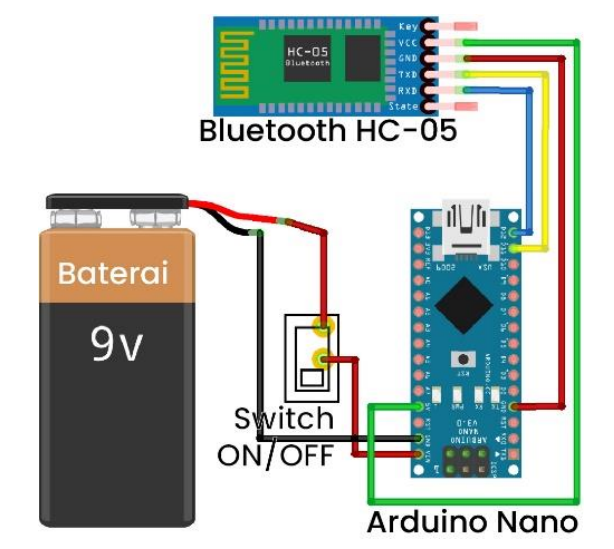

Gambar 7. Perancangan Perangkat Keras Sepeda Motor

Rangkaian tersebut terdiri dari beberapa perangkat yaitu, modul Bluetooth HC-05 sebagai master, baterai 9v sebagai daya pada Arduino, switch ON/OFF, dan Arduino Nano sebagai perangkat mikrocontroller. Perancangan perangkat keras helm dapat dilihat seperti pada Gambar 8. 


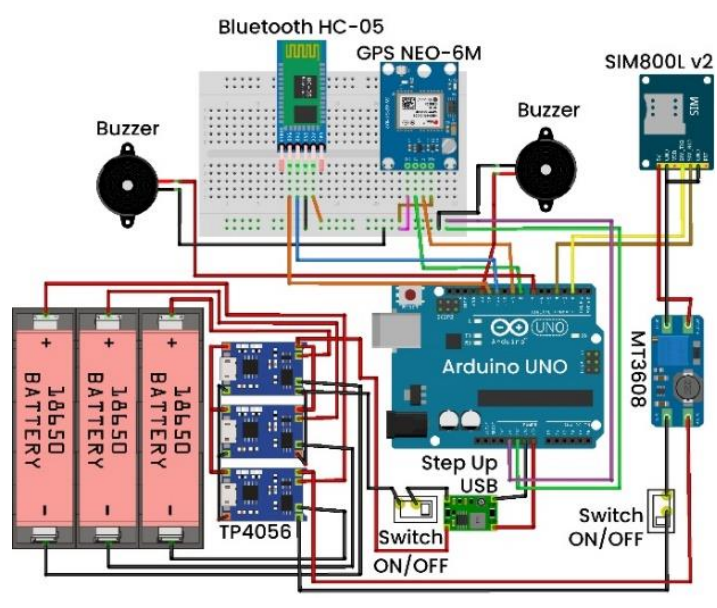

Gambar 8. Perancangan Perangkat Keras Helm

Rangkaian tersebut terdiri dari beberapa perangkat yaitu modul Bluetooth HC-05 sebagai slave, modul GPS NEO-6M untuk mendapatkan latitude dan longitude, tiga baterai 18650 sebagai daya pada Arduino. Terdapat SIM800L v2, dua buzzer sebagai alarm pada helm, dua Switch ON/OFF, tiga Modul Charger TP4056 untuk mengisi daya baterai 18650. Terdapat modul Step Up USB untuk menaikan tegangan baterai dari 3,7 volt menjadi 5 volt pada Arduino, Modul Step Up MT3608 untuk menaikan tegangan baterai dari 3.7 volt menjadi 5 volt pada SIM800L v2. Modul SIM800L v2 digunakan untuk mengirim data menggunakan jaringan internet dan Arduino UNO sebagai perangkat mikrocontroller.

\section{Hasil dan Pembahasan}

Sistem yang dihasilkan dari penelitian ini merupakan rancangan perangkat keras helm dan perangkat keras motor berbasis Internet of Things, dan perangkat lunak aplikasi Android. Aplikasi Android menggunakan Firebase Realtime Database sebagai basis data yang dapat menyimpan dan menampilkan data yang telah di proses secara realtime.

\subsection{Perangkat Keras (Hardware)}

Rancangan dari perangkat keras dalam sistem pendeteksi helm ini terdiri dari perangkat keras pada motor dan perangkat keras pada helm. Masing-masing perangkat keras tersebut memiliki komponen dan fungsi yang berbeda. Hasil dari perancangan perangkat keras pada motor dapat dijelaskan pada Gambar 9.

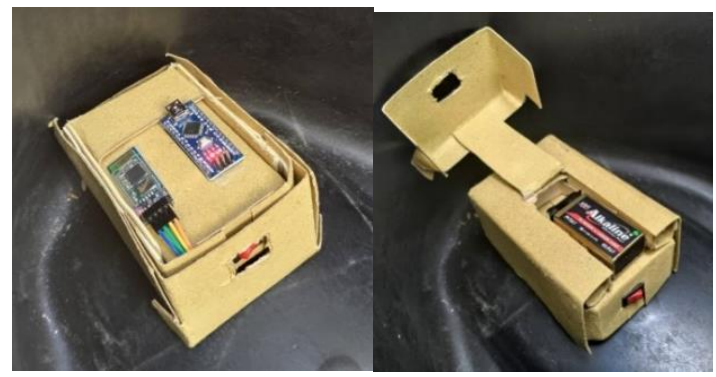

Gambar 9. Hasil Perancangan Perangkat Motor sebagai Master
Perangkat tersebut disusun dengan casing menggunakan kertas karton yang berukuran cukup kecil yaitu dengan panjang $20 \mathrm{~cm}$ dan lebar $15 \mathrm{~cm}$, sehingga dapat diletakan pada bagasi sepeda motor. Perangkat keras motor tersebut terdapat Arduino, kemudian modul Bluetooth HC-05 yang dikonfigurasikan sebagai master, dan terdapat baterai $9 \mathrm{v}$ yang digunakan sebagai daya atau sumber energi dari perangkat tersebut, dan terdapat saklar atau switch ON/OFF untuk menyalakan atau mematikan perangkat tersebut. Hasil dari perancangan perangkat keras pada motor dapat dijelaskan seperti pada Gambar 10.

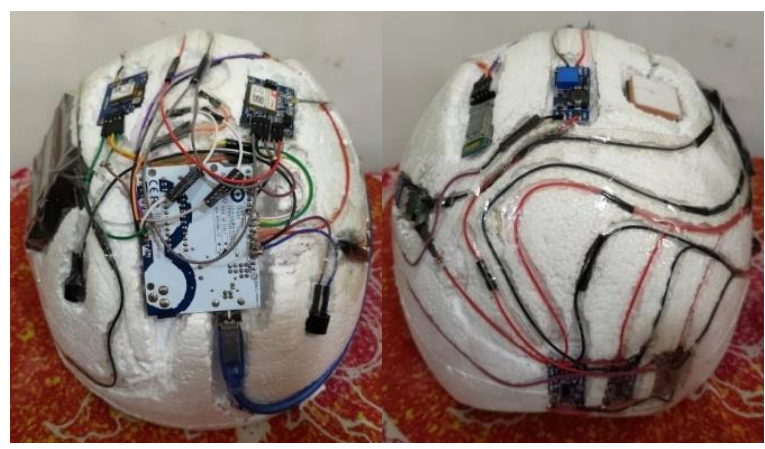

Gambar 10. Hasil Perancangan Perangkat Helm sebagai Slave

Perangkat tersebut disusun menggunakan styrofoam yang terdapat dalam helm yang terdapat Arduino Uno, modul Bluetooth HC-05 yang dikonfigurasikan sebagai slave, GPS Neo-6m, SIM800L, dan dua buzzer. Baterai 18650 digunakan sebagai daya atau sumber energi dari perangkat tersebut, Modul Charger TP4056 digunakan untuk mengisi daya baterai menggunakan kabel data micro-USB, dan Modul Step Up USB. Terdapat saklar atau switch ON/OFF untuk menyalakan atau mematikan perangkat keras pada helm. Ketika pengguna sedang tidak menggunakan helm tersebut atau diletakkan pada motor, perangkat pada helm dapat dihidupkan untuk mengaktifkan proses dari sistem pendeteksi tersebut. Perangkat keras ini dapat kompatibel dengan helm ukuran S keatas, dikarenakan perangkat yang ada pada helm tersebut cukup banyak dan memerlukan ruang yang cukup untuk merancang perangkat keras pada helm

\subsection{Perangkat Lunak (Software)}

Perangkat lunak yang telah dirancang menggunakan sistem operasi Android. Aplikasi Android ini berjalan dengan sistem operasi Android Jelly Bean (v4.3), yang bertujuan sebagai media penjelasan hasil dari data yang direkam dari perangkat keras. Tampilan dari aplikasi Android yang telah dirancang dapat dilihat seperti pada Gambar 11.

Tampilan tersebut terdapat Toolbar yang berisikan tombol reload di bagian atas kanan yang digunakan untuk me-refresh posisi dari marker pada map yang mewakilkan posisi dari helm tersebut. Marker pada maps terdapat popup yang dapat ditekan dan akan menuju ke aplikasi Google Maps yang dapat digunakan untuk melakukan direction dari posisi pengguna ke helm

DOI: https://doi.org/10.29207/resti.v5i5.3507

Lisensi: Creative Commons Attribution 4.0 International (CC BY 4.0) 
tersebut. Bagian bawah aplikasi terdapat Bottom Sheet sebanyak 10 kali, didapatkan hasil yaitu pada jarak awal yang terdapat informasi detail dari helm pengguna, hingga 10 meter bluetooth masih dapat melakukan seperti status helm, latitude, longitude, lokasi helm, dan koneksi master dan slave, dimana master mengirimkan alarm helm yang terdapat tombol untuk mengaktifkan data "1" dan slave menerima data tersebut, dan alarm atau mematikan alarm helm tersebut.

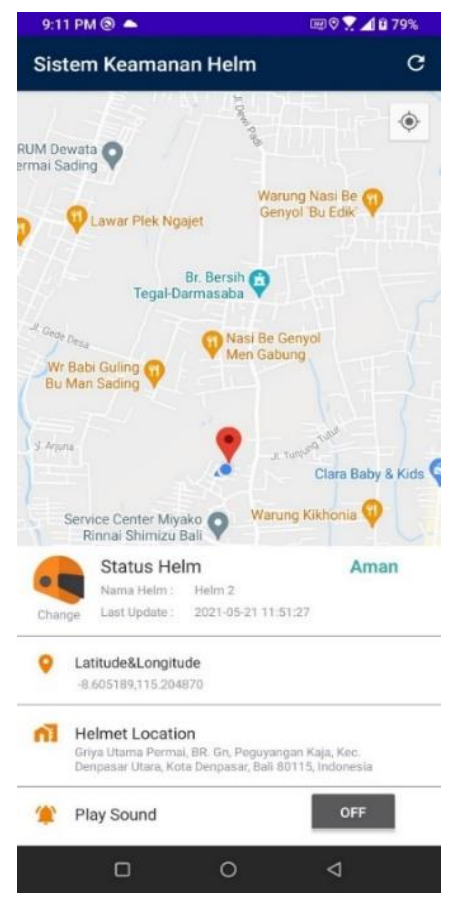

Gambar 11. Tampilan Aplikasi Android Sistem

\subsection{Hasil Uji Coba Modul Bluetooth HC-05}

Modul Bluetooth HC-05 pada penelitian ini terdapat dua buah modul yang terdapat pada perangkat motor dan helm kedua modul tersebut digunakan sebagai koneksi master dan slave. Pengujian yang dilakukan dari modul ini yaitu seberapa jauh jarak yang dapat dilakukan agar master dan slave dapat terkoneksi dan master dapat mengirimkan data ke slave. Pengujian dari modul bluetooth ini dapat dilihat seperti pada Tabel 1.

Tabel 1. Pengujian Bluetooth HC-05

\begin{tabular}{|c|c|c|c|c|c|}
\hline $\begin{array}{l}\text { Uji } \\
\text { Coba } \\
\mathrm{Ke}-\end{array}$ & $\begin{array}{l}\text { Jarak } \\
\text { Master } \\
\text { dan Slave } \\
\text { (meter) }\end{array}$ & $\begin{array}{l}\text { Master } \\
\text { Mengir } \\
\text { im }\end{array}$ & $\begin{array}{l}\text { Slave } \\
\text { Mene } \\
\text { rima }\end{array}$ & $\begin{array}{l}\text { Keterang } \\
\text { an }\end{array}$ & $\begin{array}{l}\text { Alarm } \\
\text { Buzzer }\end{array}$ \\
\hline 1 & 2 & 1 & 1 & Terkoneksi & Mati \\
\hline 2 & 4 & 1 & 1 & Terkoneksi & Mati \\
\hline 3 & 6 & 1 & 1 & Terkoneksi & Mati \\
\hline 4 & 8 & 1 & 1 & Terkoneksi & Mati \\
\hline 5 & 9 & 1 & 1 & Terkoneksi & Mati \\
\hline 6 & 10 & 1 & 1 & Terkoneksi & Mati \\
\hline 7 & 11 & 1 & 0 & $\begin{array}{l}\text { Tidak } \\
\text { Terkoneksi }\end{array}$ & Menyala \\
\hline 8 & 12 & 1 & 0 & $\begin{array}{l}\text { Tidak } \\
\text { Terkoneksi }\end{array}$ & Menyala \\
\hline 9 & 13 & 1 & 0 & $\begin{array}{l}\text { Tidak } \\
\text { Terkoneksi }\end{array}$ & Menyala \\
\hline 10 & 14 & 1 & 0 & $\begin{array}{l}\text { Tidak } \\
\text { Terkoneksi }\end{array}$ & Menyala \\
\hline
\end{tabular}
Tabel 1 merupakan hasil dari pengujian modul Bluetooth dari Firebase menggunakan modul SIM800L v2. HC-05 yang digunakan pada sistem sebagai master dan Berdasarkan hasil pengujian yang dilakukan sebanyak slave. Berdasarkan hasil pengujian yang dilakukan 10 kali, didapatkan waktu membaca data yang berbedabuzzer pada perangkat keras helm tidak akan menyala meter, 12 meter, dan seterusnya bluetooth tidak dapat terkoneksikan dan slave tidak menerima apa yang dikirimkan dari master sehingga slave akan menampilkan data " 0 " pada sistem yang berarti helm sedang tercuri, dan alarm buzzer pada perangkat keras helm akan menyala.

\subsection{Hasil Uji Coba Mengirim dan Membaca Data dari Firebase}

Setelah berhasil melakukan uji coba terhadap modul Bluetooth HC-05, selanjutnya yaitu menguji modul SIM800L v2 yang digunakan untuk mengkoneksikan sistem ke internet menggunakan jaringan GPRS. Pengujian ini terdiri dari dua tahapan yaitu mengirim data ke Firebase dan membaca data dari Firebase. Pengujian mengirim data ke Firebase dapat dilihat seperti pada Tabel 2 berikut.

Tabel 2. Pengujian Mengirim Data ke Firebase Menggunakan

\begin{tabular}{lllll}
\hline $\begin{array}{l}\text { Uji Coba } \\
\text { Ke- }\end{array}$ & $\begin{array}{l}\text { Waktu } \\
\text { Pengirim } \\
\text { an }\end{array}$ & $\begin{array}{l}\text { Waktu } \\
\text { diterima } \\
\text { Firebase }\end{array}$ & $\begin{array}{l}\text { Selisih } \\
\text { Waktu } \\
\text { (detik) }\end{array}$ & $\begin{array}{l}\text { Keterang } \\
\text { an }\end{array}$ \\
\hline 1 & $18: 13: 22$ & $18: 13: 23$ & 1 & Berhasil \\
2 & $18: 13: 48$ & $18: 13: 49$ & 1 & Berhasil \\
3 & $18: 14: 01$ & $18: 14: 02$ & 1 & Berhasil \\
4 & $18: 14: 13$ & $18: 14: 15$ & 2 & Berhasil \\
5 & $18: 14: 26$ & $18: 14: 27$ & 1 & Berhasil \\
6 & $18: 14: 39$ & $18: 14: 40$ & 1 & Berhasil \\
7 & $18: 14: 52$ & $18: 14: 53$ & 1 & Berhasil \\
8 & $18: 15: 05$ & $18: 15: 06$ & 1 & Berhasil \\
9 & $18: 15: 17$ & $18: 15: 18$ & 1 & Berhasil \\
10 & $18: 15: 30$ & $18: 15: 31$ & 1 & Berhasil \\
\hline Rata-rata & \multicolumn{5}{r}{1,1} & \\
\hline Tingkat & & & & $100 \%$ \\
Berhasil & & & & Berhasil \\
\hline
\end{tabular}

Tabel 2 merupakan hasil dari pengujian mengirim data ke Firebase menggunakan modul SIM800L v2. Berdasarkan hasil pengujian yang dilakukan sebanyak 10 kali, didapatkan waktu pengiriman dan waktu diterima Firebase yang berbeda-beda. Selisih waktu pengiriman rata-rata adalah 1,1 detik untuk menyimpan data dari perangkat keras ke Firebase, dan semua pengujian tersebut berhasil dilakukan untuk menyimpan data ke Firebase. Rata-rata selisih mengirim data tersebut juga lebih cepat dibandingkan penelitian sebelumnya yang disajikan dalam penulisan ini, yaitu 2,1 detik dan menggunakan metode penyimpanan data yang berbeda yaitu Broker MQTT Adafruit IO. Pengujian membaca data dari Firebase dapat dilihat seperti pada Tabel 3 . atau mati. Pengujian master dan slave dengan jarak 11 
beda. Selisih waktu membaca data mendapatkan rata- menghidupkan alarm yang berfungsi untuk mengetahui rata 5,3 detik untuk membaca data dari Firebase ke posisi dari helm tersebut jika pengguna sudah mendekati perangkat keras, dan semua pengujian tersebut berhasil helm tersebut. Alarm pada perangkat slave akan dilakukan untuk membaca data dari Firebase.

Tabel 3. Pengujian Membaca Data dari Firebase Menggunakan Sim8001 V2

\begin{tabular}{lllll}
\hline $\begin{array}{l}\text { Uji Coba } \\
\text { Ke- }\end{array}$ & $\begin{array}{l}\text { Waktu } \\
\text { Membaca } \\
\text { Data }\end{array}$ & $\begin{array}{l}\text { Waktu Data } \\
\text { diterima } \\
\text { Perangkat } \\
\text { Helm }\end{array}$ & $\begin{array}{l}\text { Selisih } \\
\text { Waktu } \\
\text { (Detik) }\end{array}$ & $\begin{array}{l}\text { Keterang } \\
\text { an }\end{array}$ \\
\hline 1 & $18: 13: 34$ & $18: 13: 44$ & 10 & Berhasil \\
2 & $18: 13: 53$ & $18: 13: 57$ & 4 & Berhasil \\
3 & $18: 14: 05$ & $18: 14: 10$ & 5 & Berhasil \\
4 & $18: 14: 18$ & $18: 14: 23$ & 5 & Berhasil \\
5 & $18: 14: 31$ & $18: 14: 36$ & 5 & Berhasil \\
6 & $18: 14: 44$ & $18: 14: 49$ & 5 & Berhasil \\
7 & $18: 14: 57$ & $18: 15: 01$ & 4 & Berhasil \\
8 & $18: 15: 09$ & $18: 15: 14$ & 5 & Berhasil \\
9 & $18: 15: 22$ & $18: 15: 27$ & 5 & Berhasil \\
10 & $18: 15: 35$ & $18: 15: 40$ & 5 & Berhasil \\
\hline Rata-rata & & & 5,3 & \\
\hline Tingkat & & & & $100 \%$ \\
Berhasil & & & & Berhasil \\
\hline
\end{tabular}

\subsection{Hasil Uji Coba Aplikasi Android}

Setelah perangkat keras diuji coba dan berhasil untuk dijalankan, pengujian terakhir dilakukan pada perangkat lunak sistem atau aplikasi Android yang digunakan pengguna sistem. Pengujian ini dilakukan untuk mengetahui apakah sistem dapat berjalan sesuai dengan harapan pengguna. Pengujian dari aplikasi Android tersebut dapat dilihat seperti pada Gambar 12.

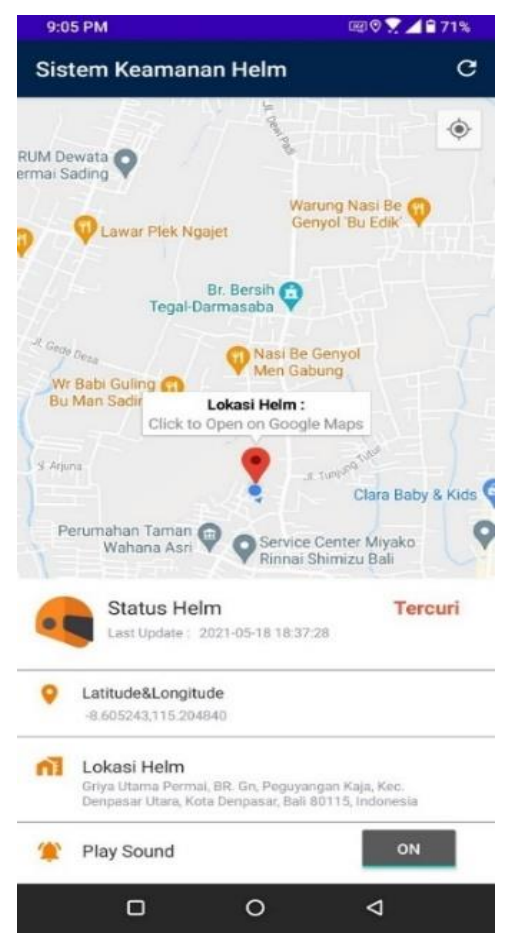

Gambar 12. Uji Coba Status Helm dan Suara Helm otomatis berbunyi jika koneksi master dan slave terputus dan pada aplikasi Android akan menampilkan status yaitu "tercuri", selanjutnya sistem aplikasi Android tersebut akan menampilkan notifikasi ke pengguna secara langsung jika helm sedang tercuri. Notifikasi pada aplikasi Android dapat dilihat seperti pada Gambar 13.

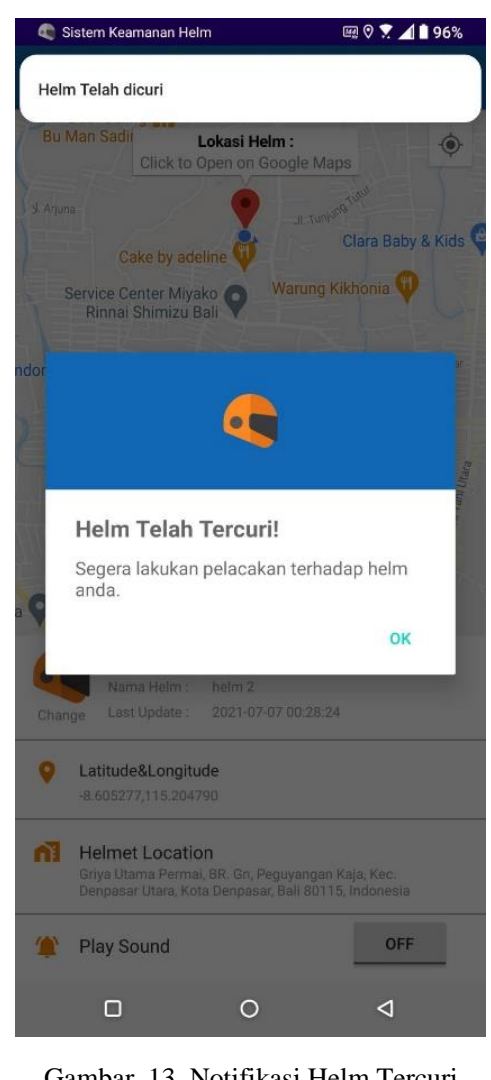

Notifikasi tersebut ditampilkan berdasarkan data dari Firebase Realtime Database. Perangkat pada slave akan mengirim/menyimpan data di Firebase yaitu " 0 " pada bluetooth, apabila koneksi master dan slave terputus. Sehingga pada sistem akan membaca data tersebut dan akan menampilkan notifikasi pada aplikasi Android.

Proses tersebut dilanjutkan dengan menekan tombol "Save Data to Your Account" yang selanjutnya akan menampilkan pop up atau dialog dengan data yang ditampilkan yaitu email pengguna yang telah login dan nama bluetooth yang selanjutnya akan disimpan menjadi nama helm pada Firebase. Pengguna dapat menekan tombol OK apabila data yang tercantum sudah benar dan data akan tersimpan pada Firebase Realtime Database.

Tampilan tersebut (Ganbar 14 dan 15) terdapat list dari helm yang dimiliki dari pengguna yang telah melakukan login dan mendaftarkan data helm ke Firebase Realtime Database. Pengguna dapat mengubah data helm yang digunakan dengan menekan salah satu data yang tersedia

Status pada helm tersebut ada dua yaitu "aman" dan "tercuri". Status aman didapatkan dari koneksi antara bluetooth master dan slave, status pada helm adalah "aman" jika bluetooth terkoneksi. Pengguna juga dapat 
dan data yang ditampilkan pada maps akan berubah Perangkat keras helm terdiri dari Bluetooth HC-05,

sesuai dengan data helm yang dipilih.

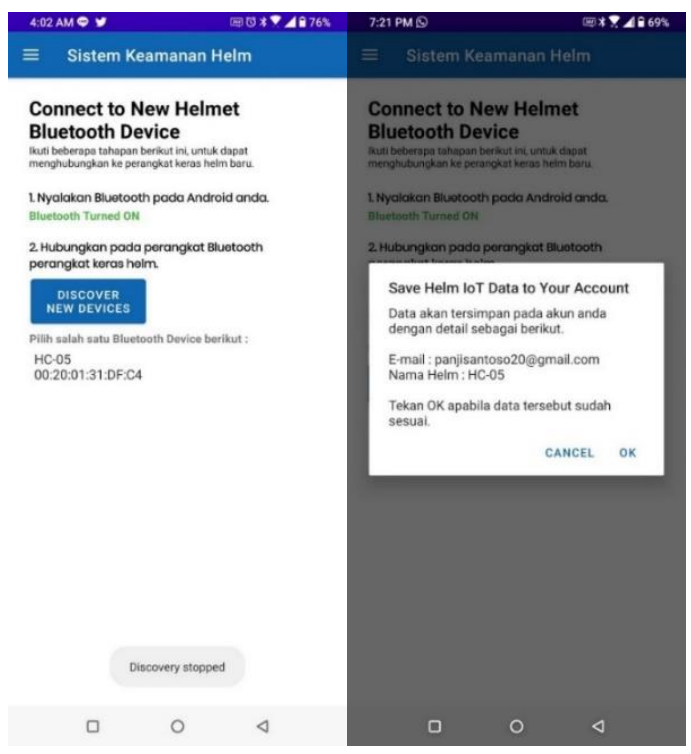

Gambar 14. Fitur Menambahkan Data Helm Baru

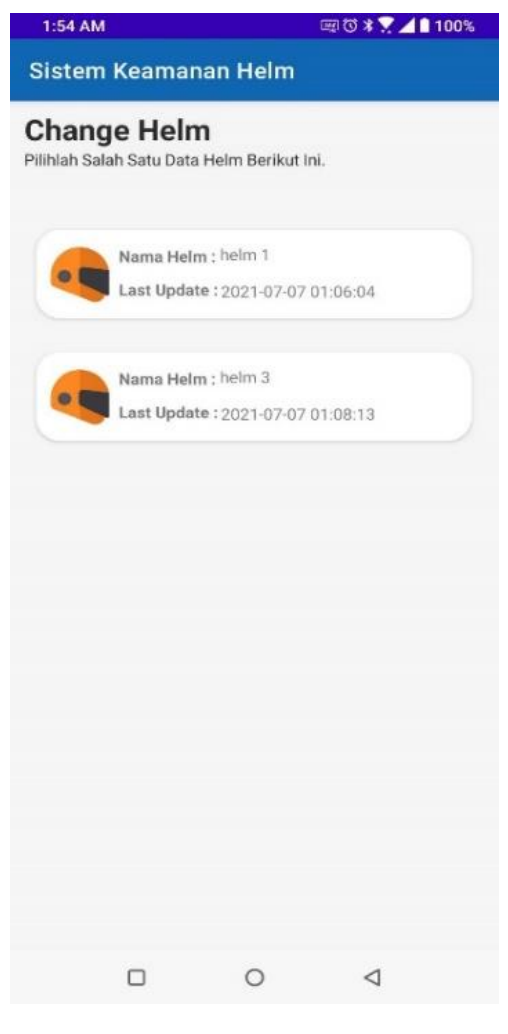

Gambar 15. Fitur Mengubah Data Helm

\section{Kesimpulan}

Kesimpulan dari penelitian Sistem Pendeteksi Pencurian Helm Berbasis Internet of Things ini yaitu, perancangan sistem pendeteksi pencurian helm ini menggunakan teknologi berbasis Internet of Things. Perancangan perangkat keras terdiri dari dua perangkat yaitu perangkat keras motor yang terdiri dari Arduino Nano, Bluetooth HC-05, Switch ON/OFF, dan baterai 9v. modul GPS NEO-6m, tiga baterai 18650, SIM800L v2, dua Buzzer, dua Switch ON/OFF, Modul Charger TP4056, Modul Step Up MT3608, Modul Step Up USB dan Arduino UNO. Modul bluetooth pada motor dikonfigurasikan sebagai master dan pada helm sebagai slave, yang berfungsi sebagai indikator keamanan pada pencurian helm. Berdasarkan uji coba, koneksi master slave akan terputus apabila melebihi jarak $10 \mathrm{~m}$ antara kedua bluetooth tersebut. Rancangan sistem dalam penelitian dapat mendeteksi adanya peristiwa pencurian helm menggunakan perangkat keras Internet of Things, dan dapat melakukan pelacakan posisi helm apabila tercuri, pada fitur maps menggunakan aplikasi Android yang sudah dirancang sebelumnya. Penggunaan Firebase dapat mendukung dalam penyusunan penelitian ini, khususnya pada fitur Firebase Realtime Database. Firebase Realtime Database dapat menyimpan data melalui perangkat keras kemudian dibaca pada aplikasi Android secara realtime. Data pada Firebase akan melakukan update secara otomatis, sehingga pada aplikasi Android akan memperbarui data tanpa harus melakukan refresh atau reload pada halaman aplikasi Android. Pengiriman data dari perangkat keras ke Firebase berhasil dilakukan, berdasarkan uji coba dihasilkan rata-rata pengiriman data yaitu 1,1 detik dan rata-rata waktu membaca data yaitu 5,3 detik. Penelitian ini terdapat kelemahan yaitu perangkat keras pada helm tidak dapat dirancang pada helm yang memiliki ukuran lebih kecil dari S. Hal tersebut dikarenakan komponen atau modul perangkat keras pada helm cukup banyak dan berukuran cukup besar. Solusi yang dapat diberikan untuk kelemahan tersebut yaitu menggunakan modul yang lebih compact atau berukuran lebih kecil, sehingga dapat dirancang pada helm yang memiliki ukuran lebih kecil dari S.

Saran yang dapat diberikan untuk pengembangan penelitian Sistem Pendeteksi Pencurian Helm ini adalah dapat dikembangan untuk menambahkan modul IoT terbaru dan fitur yang baru agar dapat mendeteksi pencurian helm yang lebih efisien, akurat dan terbaharukan. Seperti menambahkan fitur untuk menghidupkan dan mematikan perangkat keras melalui aplikasi Android, dan dapat mengetahui indikator kapasitas baterai yang tersisa pada perangkat keras helm dan motor. Pengembangan sistem selanjutnya diharapkan untuk menambahkan modul kamera pada motor yang dapat digunakan untuk mendeteksi wajah disekitar sepeda motor pengguna sistem keamanan ini. Sehingga sistem dapat menyimpan dataset wajah pengguna atau pemilik sistem, dan dapat mendeteksi wajah yang bukan merupakan pengguna sistem dengan dugaan sebagai pencuri.

\section{Daftar Rujukan}

[1] F. Aryaviocholda, M. Hannats, H. Ichsan, and A. S. Budi, "Rancangan Sistem Pendeteksi Pencurian Helm Menggunakan 
Protokol MQTT Dan Bluetooth HC-05 Berbasis Arduino," 2020. https://j-ptiik.ub.ac.id/index.php/j-ptiik/article/view/6969

[2] Y. Efendi, "Internet Of Things (Iot) Sistem Pengendalian Lampu Menggunakan Raspberry Pi Berbasis Mobile," Jurnal Ilmiah Ilmu Komputer, vol. 4, no. 2, pp. 21-27, 2018. https://doi.org/10.35329/jiik.v4i2.41

[3] E. A. Siddiq and H. Effendi, "Sistem Monitoring Sepeda Motor Berbasis Mikrokontroler Menggunakan GPS," (Jurnal Teknik Elektro Dan Vokasional, vol. 06, no. 02, pp. 383-390, 2020. https://doi.org/10.24036/jtev.v6i2.109397

[4] I. Kholilah and A. R. al Tahtawi, "Aplikasi Arduino-Android untuk Sistem Keamanan Sepeda Motor," Jurnal Teknologi Rekayasa, vol. $1, \quad$ no. $1, \quad$ p. 53, 2017. http://dx.doi.org/10.31544/jtera.v1.i1.2016.53-58

[5] P. V. G. Y. R. Kalshetty, "Bluetooth Based Smart Automation System Using Android," International Journal of Science and Research (IJSR), vol. 6, no. 5, pp. 1003-1006, 2017. https://www.ijsr.net/archive/v6i5/3051709.pdf

[6] D. Wulandari and Willyansah, "Sistem Kontrol Kendaraan Berbasis IOT," Jaringan Sistem Informasi Robotik, vol. 2, no. 02, pp. $1-6,2018$. http://ojsamik.amikmitragama.ac.id/index.php/js/article/view/41
7] D. Hermanto, Yamato, and A. R. Machdi, "Perancangan Sistem Keamanan Berkendara Roda Dua Menggunakan Arduino Uno Berbasis Sms," Jurnal Online Mahasiswa (JOM) Bidang Teknik Elektro, vol. 1, no. 1, pp. 1-10, 2016, [Online]. Available: http://jom.unpak.ac.id/index.php/teknikelektro/article/view/506

8] D. Pangestu, A. Muid, and U. Ristian, "Purwarupa Sistem Informasi Titik Lokasi Dan Intensitas Curah Hujan Di Kota Pontianak Berbasis Website," Jurnal Coding, Sistem Komputer Untan, vol. 6, no. 3, pp. 247-254, 2018. http://dx.doi.org/10.26418/coding.v6i3.29059

[9] Dony Novaliendry and S. Andriani, "English Edugame Application for Childhood base on Android," Jurnal RESTI (Rekayasa Sistem dan Teknologi Informasi), vol. 4, no. 1, pp. 187-192, 2020. https://doi.org/10.29207/resti.v4i1.1622

[10] Ilham Firman Maulana, "Penerapan Firebase Realtime Database pada Aplikasi E-Tilang Smartphone berbasis Mobile Android," Jurnal RESTI (Rekayasa Sistem dan Teknologi Informasi), vol. 4, no. 5, pp. 854-863, 2020. https://doi.org/10.29207/resti.v4i5.2232

[11] K. N. M. Ngafidin, A. Arista, and R. N. S. Amriza, "Implementasi Firebase Realtime Database pada Aplikasi FeedbackMe," Resti, vol. $1, \quad$ no. $10, \quad$ pp. 327-334, 2021. https://doi.org/10.29207/resti.v5i2.2909 